\title{
Some medical and other risk factors for current cesarean section in a Jakarta hospital
}

\author{
Endang Poedjiningsih", Bastaman Basuki ${ }^{\dagger}$, A.W. Supardi
}

\begin{abstract}
Abstrak
Akhir-akhir ini prevalensi seksio saesaria (SS) meningkat di beberapa negara termasuk Indonesia. Namun, di Indonesia belum pernah dilakukan penelitian komprehensif tentang faktor risiko yang berkaitan dengan SS lari 1 Juli 2000 sampai 31 Januari 2001 . dengan memakai data yang diekstraksi dari catatan medik Rumah Sakit Faimahirkan per vaginam. Untuk setiap kasus dipilih secara Kasus ialah yang melahirkan dengan cara SS, dan kontrol ialah yang melahirkan per 2000 . Subjek yang mengalami gawat janin mempunyai acak seorang kontrol sesuai dengan periode sebelum atau setelah 18 okrober 2000. Subje odds suaian $(O R)=544,86 ; 95 \%$ interval 544-lipat kenaikan risiko SS dibandingkan dengan yang tidak gawal janin tidak mempunyai distosia, yang distosia mempunyai kepercayaan $(C I)=71,85-4131,781$. Di samping itu, relatif terhadap yang tak sedangkan yang pernah SS mempunyai risiko 30 kali risiko risiko 143 kali risiko $S S(O R$ suaian $=52,86 ; 95 \% C I=52,86-391,17)$. Sedangkan SS dibandingkan dengan subjek yang tidak pernah SS $(O R$ suaian $=30,23,95 \%$ lebih kecil $($ OR suaian $=0,20 ; 95 \%$ CI $=0,11$. yang membayar tidak tunai, mereka yang mebayar tunai mempunyai risiko mo lis lainnya, gawat janin, dan yang membayar tidak 0,34). Sebagai kesimpulan, kepernahan SS, distosia, pre eklam
\end{abstract}

tunai mempertinggi risiko SS. (Med J Indones 2001; 10: 230-4)

\begin{abstract}
For the last years the prevalence of cesarean section (CS) increased in several countries as well as in Indonesia. In Indonesia there was no comprehensive study on risk factors related to CS. This case-control study was conducted at Fatmawati Hospital in Jakarta from 1 July 2000 until 31 January 2001. Data was extracted from available medical records. Cesarean section cases were selected delivery through laparotomy. The control group consisted of subjects having vaginal deliveries. randomly a control based on the date before or after 18 October 2000 . Subjects who $54.86 ; 95 \%$ confidence intervals $(C I)=71.85$ to be CS relative to those who did not have fetal distress [adjusted odds ratio (OR) 4131.78]. Furthermore, relative those who did not have dystocia, those who had who ever had previous CS had 30 times increased (adjusted $O R=52.86 ; 95 \% C I=52.86-391.17)$. In term of pretious $O R=30.23 ; 95 \% C I=12.06-75.57$ ). In contrast, compared risk to be CS compared with the subjects who never had CS (adjusted OR risk of $80 \%$ (adjusted $O R=0.20 ; 95 \% C I=0.11-0.34$ ). In with those who non cash payment, those who paid in cash had a lowered nisk of fetal distress, and non cash hospitalization expenses conclusion, previous CS, dystocia, pre eclampsia, other
\end{abstract}

increased risk of CS. (Med J Indones 2001; 10: 230-4)

Keywords: cesarean section, risk factors

Recently, the prevalence of cesarean section (CS) increased in several countries ${ }^{1,2}$ The same condition occurred in Indonesia. ${ }^{3}$ At Dr. Cipto Mangunkusumo Hospital Jakarta, a national top referral hospital in Indonesia, the section rate was relatively high and

\footnotetext{
* Fatmawati Hospital Jakarta, Indonesia

+ Department of Community Medicine, Faculty of Medicine, University of Indonesia, Jakarta, Indonesia
}

almost reached $40 \%$ in 2000 . At Fatmawati Hospital, a teaching and referral hospital in southern part of Jakarta, the proportion between CS and vaginal deliveries was $31 \%$ in 1999 (personal communication).

Several medical and socio economic risk factors related to SC were reported. ${ }^{1-4} \mathrm{CS}$ more likely is performed among women who have high annual come more than less annual income, and there is an indication that malpractice related to $\mathrm{CS}$ $^{1-3}$ 
Recently, the Ministry of Health of the Republic of Indonesia indicated that there are increase number of CS with unclear indications in several hospitals in Indonesia. ${ }^{5}$ However, in Indonesia there was no comprehensive study on risk factors for CS. Therefore, we conducted a study to analyze the medical and non medical risk factors for SC.

\section{METHODS}

This case-control study was conducted at Fatmawati Hospital (a teaching and referral hospital) in Jakarta from 1 July 2000 until 31 January 2001. Data was extracted from the available medical records.

Cesarean section cases were taken during the period of the study. Cesarean section was defined as a fetal delivery method through laparotomy or hysterectomy except due to uterine rupture, placenta previa, carcinoma cervix, herpes genitalia. ${ }^{6-8}$

The control group consisted of women who had vaginal deliveries (spontaneous delivery extraction version, vacuum, or forceps deliveries) ${ }^{6-8}$ For each case we selected randomly a control from eligiblè would be controls based on the date before or after 18 October 2000 (the date of Ministry start of Health medical audits).

For cases and controls, information collected were some demographic characteristics (age, education, occupation), obstetrics and gynecologic risk factors (pregnancy, parity, previous SC, previous abortion, pre-eclampsia, fetal distress, dystocia), nursing class, and method of payment.

Previous cesarean section was defined as any previous CS. Dystocia is a failure of delivery process due to cephalo pelvic disproportion, mal-position, malpresentation, macrosomia, meningocele, hydrocephalus, gemeli, primary inertia uteri, secondary inertia uteri, or failed induction. ${ }^{6-8}$

Other medical indications included intra partum infection related to induction, heart failure, other heart disease, other diseases, diabetes mellitus, infertility, ante partum bleeding. ${ }^{6-8}$

For this analysis we categorized education as follow. Lower education subgroup consisted of those who were illiterate, have not finished, or finished primary school. Middle education subgroup included those who had junior or senior high school education. While high education included those who finished college or university.

Occupation was the last occupation at the time of the delivery. Jobless included housewives, while any jobs included labors, merchants, private and government employees, hospital staff, etc.). Gravidity consisted of two subgroups (first gravida, and second gravida or more).

We categorized parity into a nulli para and non nulli para. Nulli para were those who never had delivered a viable fetus. Nursing class was divided into two subgroups. Low nursing class was third or non airconditioned second class, while high nursing class consisted of air-conditioned second class, first class, very and super important classes. Methods of payments were at the of discharge (cash and non cash payment). Non cash payment included installment, insurances, or credit cards).

Statistical analyses were done using STATA 6.0 software. ${ }^{9}$ A number of risk factors were examined whether they were potential confounders and/or effect modifiers. Unconditional logistic regression analysis ${ }^{10}$ was used in order to determine the confounding effects and to determine the risk factors for CS. Confounders were estimated by the method of maximum likelihood. Ninety-five percent confidence intervals were based on the standard error of coefficient estimates. Relative risks represented by odds ratios (OR) were estimated by the methods of maximum likelihood. ${ }^{10} \mathrm{~A}$ risk factor was considered to be a potential confounder if in the univariate test it had a $P$-value $<0.25$ which would be considered as a candidate for the multivariate model along with all known risk factors for CS. ${ }^{11}$

\section{RESULTS}

During the period of 1 July 2000 until 31 January 2001 there were 1136 deliveries consisted of 365 CS and 859 vaginal deliveries. We excluded 92 subjects with incomplete data (seven CS subjects and 85 vaginal delivery subjects). Furthermore we excluded 47 CS subjects (CS cases who had placenta previa, carcinoma cervix, or herpes genitalia leaving $311 \mathrm{CS}$ in this analysis. We selected randomly 311 out of 774 vaginal delivery subjects, based on the date before and after 18 October 2000. 
Cesarean section and vaginal delivery subjects were similarly distributed in respect to age and pregnancy period. Cesarean section subjects were more likely than vaginal delivery subjects with respect to high education and had any jobs. However, CS subjects were less likely than vaginal delivery subjects with respect to middle education (Table 1 ).

Table 1. Some demographic characteristics of subjects

\begin{tabular}{|c|c|c|c|c|}
\hline & \multicolumn{2}{|c|}{$\begin{array}{l}\text { Vaginal } \\
\text { delivery } \\
(\mathrm{N}=311)\end{array}$} & \multicolumn{2}{|c|}{$\begin{array}{c}\text { Cesarean } \\
\text { section } \\
(\mathrm{N}=311)\end{array}$} \\
\hline & $\mathrm{n}$ & $\%$ & $\mathrm{n}$ & $\%$ \\
\hline \multicolumn{5}{|l|}{ Age group } \\
\hline $17-19$ years & 12 & 3.9 & 12 & 3.9 \\
\hline $20-34$ years & 247 & 79.2 & 236 & 76.2 \\
\hline $35-47$ years & 52 & 16.7 & 62 & 19.9 \\
\hline \multicolumn{5}{|c|}{ Length of pregnancy } \\
\hline 20-27 weeks & 5 & 1.6 & 1 & 0.3 \\
\hline $28-37$ weeks & 55 & 17.7 & 50 & 16.1 \\
\hline $38-43$ weeks & 251 & 80.7 & 260 & 83.6 \\
\hline \multicolumn{5}{|l|}{ Education } \\
\hline Low & 49 & 15.8 & 47 & 15.1 \\
\hline Middle & 215 & 69.1 & 196 & 63.0 \\
\hline High & 47 & 15.1 & 68 & 21.9 \\
\hline \multicolumn{5}{|l|}{ Occupation } \\
\hline Jobless & 239 & 76.9 & 228 & 73.3 \\
\hline Any jobs & 72 & 23.1 & 83 & 36.7 \\
\hline
\end{tabular}

Table 2 shows that CS and vaginal delivery subjects were similarly distributed in respect to pregnancy and parity. However, CS subjects were more likely than vaginal delivery subjects with respect to previous abortion and nursing class.

Table 2. Some obstetrics, gynecological, and economic characteristics of subjects

\begin{tabular}{|c|c|c|c|c|}
\hline & \multicolumn{2}{|c|}{$\begin{array}{l}\text { Vaginal } \\
\text { delivery } \\
(\mathrm{N}=311)\end{array}$} & \multicolumn{2}{|c|}{$\begin{array}{c}\text { Cesarean } \\
\text { section } \\
(\mathrm{N}=311)\end{array}$} \\
\hline & $\mathrm{n}$ & $\%$ & $n$ & $\%$ \\
\hline \multicolumn{5}{|l|}{ Gravida } \\
\hline Primi gravida & 128 & 41.2 & 123 & 39.6 \\
\hline Multi gravida & 183 & 58.8 & 188 & 60.5 \\
\hline \multicolumn{5}{|l|}{ Parity } \\
\hline Multi parous & 175 & 56.3 & 171 & 55.0 \\
\hline Nuly parous & 136 & 43.7 & 140 & 45.0 \\
\hline \multicolumn{5}{|c|}{ Previous abortion } \\
\hline Never & 280 & 90.0 & 262 & 84.2 \\
\hline Ever & 31 & 10.0 & 49 & 15.8 \\
\hline \multicolumn{5}{|l|}{ Nursing class } \\
\hline Low & 265 & 85.2 & 245 & 78.9 \\
\hline High & 46 & 14.8 & 66 & 21.2 \\
\hline
\end{tabular}

Our final model on the relationship between some risk factors and CS was shown on Table 3.

The model indicates that those who had previous CS, dystocia, pre eclampsia, and other medical indications, or fetal distress had increased risk to have CS. The most prominent is fetal distress. Subjects who had fetal

Table 3. Relationship between some medical indications, method of payment and risk of current cesarean section

\begin{tabular}{|c|c|c|c|c|c|c|}
\hline & \multicolumn{2}{|c|}{$\begin{array}{c}\text { Vaginal delivery } \\
(\mathrm{N}=311) \\
\end{array}$} & \multicolumn{2}{|c|}{$\begin{array}{c}\text { Cesarean section } \\
(\mathrm{N}=311) \\
\end{array}$} & \multirow[t]{2}{*}{ Odds ratio* } & \multirow[t]{2}{*}{$\begin{array}{l}95 \% \text { confidence } \\
\text { interval }\end{array}$} \\
\hline & $\mathrm{n}$ & $\%$ & $\mathrm{n}$ & $\%$ & & \\
\hline \multicolumn{7}{|c|}{ Previous cesarean section } \\
\hline \multicolumn{7}{|c|}{ Never } \\
\hline \multirow[t]{2}{*}{ Ever } & 303 & 97.4 & 272 & 87.5 & 1.00 & Reference \\
\hline & 8 & 2.6 & 39 & 12.5 & 30.23 & $12.09-75.57$ \\
\hline \multicolumn{7}{|l|}{ Dystocia } \\
\hline No & 306 & 98.4 & 197 & 63.3 & 1.00 & Reference \\
\hline Yes & 5 & 1.6 & 114 & 36.7 & 143.80 & $52.86-191.87$ \\
\hline \multicolumn{7}{|c|}{ Pre eclampsia } \\
\hline No & 283 & 91.0 & 271 & 87.1 & 1.00 & Reference \\
\hline Yes & 28 & 9.0 & 40 & 12.9 & 8.10 & $4.09-16.04$ \\
\hline \multicolumn{7}{|c|}{ Other medical indications } \\
\hline None & 273 & 87.8 & 249 & 80.1 & 1.00 & Reference \\
\hline Any & 38 & 12.2 & 62 & 19.9 & 8.10 & $4.12-14.44$ \\
\hline \multicolumn{7}{|c|}{ Fetal distress } \\
\hline No & 3101 & 99.7 & 227 & 73.0 & 1.00 & Reference \\
\hline Yes & & 0.3 & 84 & 27.0 & 544.86 & $71.85-4131.78$ \\
\hline \multicolumn{7}{|c|}{ Methods of payment } \\
\hline Non cash & 59 & 19.0 & 149 & 47.9 & 1.00 & Reference \\
\hline Cash & 252 & 81.0 & 162 & 52.1 & 0.20 & $0.11-0.34$ \\
\hline
\end{tabular}

* Adjusted odds ratio toward each others 
distress had 544-folds increased risk to be CS relative to those who did not have fetal distress. The second prominent risk factor was dystocia. Relative those who did not have dystocia, those who had dystocia had 143 times increased risk to have CS. In term of previous CS, subjects who ever had previous CS had 30 times increased risk to be CS compared with the subjects who never had CS. In contrast, subjects who paid cash had a lowered risk to be CS. Compared with those who paid non cash, those who paid hospitalization cost in cash had a lowered risk of $80 \%$.

\section{DISCUSSION}

There are several limitations that must be considered in the interpretation of our findings such as following. Firstly, our data is come from a relatively short period, from 1 July 2000 to 31 January 2001 (7 months). Our data most likely not is a representative sample for the whole CS problems at the hospital. In addition, our data came from a teaching, referral, and government hospital. This hospital serves government and private insurance schemes for further treatment including CS, and does not fix catchment areas. Therefore, most likely our data do not reflex a certain community in term CS problems.

Secondly, our data were extracted from the available routine medical records filled by different treating physicians at the hospital. In addition, some medical records had missing data (characteristic of subjects, obstetric history, nursing class, and methods of payment) that were needed for this study. Thirdly, our analysis was limited to some medical and non medical risk factors. Therefore, we could not analyze the whole existing risk factors.

In spite of these limitations, the attending physicians at the hospital were qualified trained properly to diagnose and treat CS. In addition, the attending physicians were supervised routinely by their supervisors based on the hospital standard of operating procedures.

Fetal distress. Our final model reveals that fetal distress is the most dominant risk factor for CS. Our finding is similar with other reports. ${ }^{1-3,6-8}$ However, our data had a wide $95 \%$ confidence intervals $(71.85$ to 4131.78 ). This wide range was due to the only one subject among the women with fetal distress who had vaginal delivery. This one referred case happened because on arrival at the hospital the woman was fully dilated for a spontaneous delivery. There was no need to perform CS.

Dystocia. Our final model shows that dystocia was the second prominent risk factor for CS (adjusted OR = 143.80 ) with a wide $95 \%$ confidence intervals. This wide range was due to a small number (five subjects) among women with vaginal delivery who had dystocia. Most of obstetrics and gynecologists at the Fatmawati Hospital will perform CS for women who have dystocia based on the standard of procedure. ${ }^{13}$ They used not to take a risk to perform vaginal deliveries for those with dystocia.

Previous cesarean section. Our study noted that previous CS is a risk factor for CS. This is in accordance with previous reports. ${ }^{1-3} \mathrm{~A}$ report from 16 hospitals in New York City ${ }^{3}$, where legal claims are common, revealed that the risk of CS to related to previous CS is 18.7 folds. While our data showed 30.2 times increased risk. Our higher finding is most likely due to the uncommon legal claims in Indonesia.

Other medical indications. Our category for other medical indications included intra partum infection related to induction, heart failure, other heart disease, other diseases, diabetes mellitus, infertility, and ante partum bleeding. The final model revealed that compared with those who did not have any other medical indications, those who had any other medical indications had an increased risk to have CS. This finding similar with other previous findings, ${ }^{1-3}$

Methods of payment. Our data reveals that subjects who paid cash had a lowered risk to be CS. Compared with those who paid non cash, those who paid hospitalization cost in cash had a lowered risk of $80 \%$. This condition most likely due to Fatmawati Hospital is a teaching, referral and government hospital. This hospital also serves government and private insurance schemes for further treatment including CS. In general, the insurance schemes do not allow spontaneous or vaginal deliveries to be referred to the higher level of medical service and hospital such as Fatmawati Hospital. In addition, in our study, the method of payment using credit card is considered as a non cash payment. As shown on Table 1, CS subjects were more likely to have high 
education. Most likely the higher educated people pay their expenses using credit cards. This caused the subjects using non cash payment (including insurance schemes and credit cards) had a higher risk to have CS compared with subjects using non cash payment.

Pre eclampsia. Our finding on pre eclampsia is in accordance with previous studies. ${ }^{1-3,14}$ However, our final model shows that compared with women without pre eclampsia, those who had pre eclampsia had an 8folds more to have CS. Our figure is higher than the previous studies. ${ }^{2}$ Our higher figure most likely due to the fact that Fatmawati Hospital is a referral, government, and reaching hospital. Most of the subjects did not have their ante natal care at the Fatmawati Hospital. They were referred at the time to deliver, therefore, the hospital did not have enough time to control their pre eclampsia.

In conclusion, previous $\mathrm{CS}$, dystocia, pre eclampsia, other medical indications, fetal distress, and non cash hospitalization expenses increased risk of CS.

\section{Acknowledgment}

We thank the management of Fatmawati Teaching Hospital to permit us to access the data on medical records for this study, and lastly, to Drs Abdul Bari Saifuddin and Jeanne A. Pawitan to review the earlier drafts of this manuscript that improved the final product.

\section{REFERENCES}

1. Roan CS. C-Section rises as view of risk changes 2001 January 20:[4 screens]. Available from URL. Http://www.icon-online.org/info/news/012901.htm.
2. Roan CS. C-Section rate rising in Southern California 2001 Feb 5:[3 screens]: Available from URL. Http://www.icononline.org/info/news/020501:htm

3. Christopher JG. Cesarian delivery risk adjustment for regional inter hospital comparisons. Am J Obst Gynecol 1999;181:1425-31.

4. Chi I, Saifuddin AB, Gunatilake DE, Wallace SL. Deliveries after cesarean birth in two Asian university hospitals. In: Potts M, Janowitz B, Fortney JA, editors. Childbirth in developing countries. Boston: MTP Press Ltd; 1983. p. 43-55.

5. Tempo interactive. Medical audit will be performed in Indonesia. 24 January 2001:[1 page]. Available from URL. Http://www.tempo.co.id/news/2001/1/24/1.1.44.id.htm.

6. Gary CF, MacDonald PC, Gant NF, Leveno KJ, Gilstrap LC III, Hankin GDV. Williams Obstetric $20^{\text {th }}$ ed. Stanford: Appleton \& Lange; 1997.

7. Benson RC, Parnoll ML,.Handbook of obstetrics and gynecology $9^{\text {th }}$ ed. Singapore: McGraw-Hill Inc; 1994.

8. Plauche WC, Morrison JC, O'Sullivan MJ. Surgical Obstetrics $1^{\text {st }}$ ed. Philadelphia: WB Saunders Coy; 1992.

9. Stata Corporation. Stata statistical software: Release 6.0. Texas: College Station; 1999.

10. Breslow NE, Day NE. Statistical Methods in Cancer Research. Vol I. The analysis of case-control studies. IARC Sci Publ No.32. Lyon: International Agency for Research on Cancer; 1980.

11. Hosmer DW, Lemeshow S. Applied logistic regression. New York: John Willey \& Sons; 1989.

12. Mozurkewich EL, Hutton EK. Elective repeat cesarean delivery versus trial of labor: AS meta-analysis of the literature from 1989 to 1999. Am J Obst Gynecol 2000;183:1187-97.

13. Fatmawati Hospital. Standard operating procedure 2000. Jakarta. The Hospital. 2000.

14. Mattar F, Sibai BM. Risk factors for maternal morbidity. Am J Obstet Gynecol 2000;182:307-12. 